\title{
Export of Asian pollution during two cold front episodes of the TRACE-P experiment
}

\section{Citation}

Mari, C., M. J. Evans, P. I. Palmer, D. J. Jacob, and G. W. Sachse. 2004. "Export of Asian Pollution During Two Cold Front Episodes of the TRACE-P Experiment." Journal of Geophysical Research 109 (D15). doi:10.1029/2003jd004307.

\section{Published Version}

doi:10.1029/2003JD004307

\section{Permanent link}

http://nrs.harvard.edu/urn-3:HUL.InstRepos:14121854

\section{Terms of Use}

This article was downloaded from Harvard University's DASH repository, and is made available under the terms and conditions applicable to Other Posted Material, as set forth at http:// nrs.harvard.edu/urn-3:HUL.InstRepos:dash.current.terms-of-use\#LAA

\section{Share Your Story}

The Harvard community has made this article openly available.

Please share how this access benefits you. Submit a story.

\section{Accessibility}




\title{
Export of Asian pollution during two cold front episodes of the TRACE-P experiment
}

\author{
C. Mari \\ Laboratoire d'Aérologie, UMR CNRS/UPS, Toulouse, France \\ M. J. Evans, P. I. Palmer, and D. J. Jacob \\ Division of Engineering and Applied Science, Harvard University, Cambridge, Massachusetts, USA
}

G. W. Sachse

NASA Langley Research Center, Hampton, Virginia, USA

Received 31 October 2003; revised 8 April 2004; accepted 6 May 2004; published 11 August 2004.

[1] Two cold front episodes were sampled during the two flights out of Yokota, Japan, during the Transport and Chemical Evolution Over the Pacific (TRACE-P) experiment during March 2001. The data from these two flights are examined using a mesoscale threedimensional model. We show how these cyclonic systems have impacted the export of pollution out of the Asian continent. We contrast the relative role of convection and ascent in the warm conveyor belts associated with the cyclone during these two episodes.

Although the necessary meteorological conditions for an efficient export of pollution are met during flight 13 (i.e., the occurrences of the warm conveyor belt near the source regions), no significant pollution is simulated in the mid-Pacific in the lower and middle troposphere. The efficient ventilation of the WCB by convection near the coast, the advection by the anticyclonical flow above $700 \mathrm{hPa}$, and the downward motion associated with the Pacific high in the remote ocean significantly prevent any long-range transport of undiluted pollution in the WCB. During flight 15 the conveyor belts have already moved to the remote ocean. The polluted plume is split by the rising air in the warm conveyor belt which transports CO-poor air northward and by the oceanic convection which transports clean air masses upward. These mechanisms lead to the dilution of Asian pollution in WCB en route to North America and add to the episodic nature of the Asian outflow by fragmenting the pollution plume. INDEX TERMS: 0365 Atmospheric Composition and Structure: Troposphere - composition and chemistry; 0368 Atmospheric Composition and Structure: Troposphere - constituent transport and chemistry; 3314 Meteorology and Atmospheric Dynamics: Convective processes; 3329 Meteorology and Atmospheric Dynamics: Mesoscale meteorology; KEYWORDS: warm conveyor belt, TRACE-P, pollution

Citation: Mari, C., M. J. Evans, P. I. Palmer, D. J. Jacob, and G. W. Sachse (2004), Export of Asian pollution during two cold front episodes of the TRACE-P experiment, J. Geophys. Res., 109, D15S17, doi:10.1029/2003JD004307.

\section{Introduction}

[2] The Pacific Ocean has been regarded as the only major region in the northern hemisphere that was "relatively" free from direct anthropogenic influences. It is now recognized that the rapidly emerging industrialized Asian continent [Streets and Waldhoff, 2000] has a significant impact on the environment in the northwestern Pacific region through the long-range transport of pollutants [Gregory et al., 1997; Xiao et al., 1997; Jaffe et al., 1999; Jaffe, 2001; Wilkening et al., 2000; Newell and Evans, 2000; Wild and Akimoto, 2001; Stohl et al., 2002]. Past studies have shown numerous occurrences of the episodic transpacific transport of pollution originating from

Copyright 2004 by the American Geophysical Union. 0148-0227/04/2003JD004307
Asia. These events are especially favorable during spring. Indeed, during spring, the convection begins and there are still fairly strong westerlies in the upper troposphere. Jaffe et al. [1999, 2003] relate pollution episodes observed in northwestern Washington State to surface emissions lifted into the free troposphere over Asia during frontal passages and transported to North America in the lower troposphere. Kritz et al. [1990] connect observations of radon-rich air over the west coast of the United States to localized lifting of pollution in cumulus updrafts over Asia followed by fast eastward advection on the anticyclonic side of the upper tropospheric jet. If the meteorological conditions are favorable, the authors find that the transit time for pollution to reach North America ranges between 2 or 3 days. The combination of fast convective transport and strong westerly flow contributes to the well known spring maximum in dust found over the western Pacific [Duce et al., 1980; Prospero 
and Savoie, 1989; Husar et al., 2001]. Convective lifting of Southeast Asian biomass burning is also primary responsible for CO plumes observed in the upper tropical troposphere [Folkins et al., 1997; Bey et al., 2001].

[3] The two main mechanisms responsible for lifting surface emissions from Asia into the middle and upper troposphere are localized deep convection and rising warm, humid air ahead of cold fronts (Warm Conveyor Belts, WCB) These two mechanisms, however, act at very different spatial and temporal scales: cloud scale and a few hours for deep convection, synoptic scale and a few days for fronts. The distinction between the rapid uplift in deep convective clouds and slow ascent in the conveyor belts associated with the cold fronts, however, remains a nontrivial exercise in particular because deep convection is often embedded in the frontal systems. At local scale, rapid convective injection yields air with a much different chemical signature than synoptic slow ascent [Pickering et al., 2001; Prather and Jacob, 1997; Collins et al., 1999; Gettelman et al., 2001]. At synoptic-scale, cold fronts associated with the eastward traveling cyclonic systems are shown to be a major transport mechanism into the western North Atlantic and Pacific with the consequence that transport events are highly episodic [Berkowitz et al., 1996; Yienger et al., 2000]. In particular, the role of the warm conveyor belts associated with cold fronts is pointed out in many studies. Warm conveyor belts are defined as rising streams of warm and humid air which flow ahead of the cold front [Browning and Roberts, 1994; Browning and Golding, 1995]. During the early stage of the cyclogenesis, if the upper-level flow is an open wave, then the warm conveyor belt rises to the upper troposphere and turns anticyclonically downstream of the cyclone. Later in the evolution of the cyclone (e.g., occlusion), if the upper-level flow is characterized by closed flow, some of the warm conveyor belt air may turn cyclonically around the low center [Schultz, 2001]. The warm conveyor belts are identified as major pathways for the export of pollution from the eastern seaboards of North America [Bethan et al., 1998; Cooper et al., 2001] and Asia [Jaffe et al., 1999; Kaneyasu et al., 2000; Miyazaki et al., 2003]. However, depending of their geographical origin (marine or continental), these warm conveyor belts range from very clean [Grant et al., 2000] to highly polluted [Stohl and Trickl, 1999]. Hannan et al. [2003] showed that, over the Pacific Ocean, the WCB can exhibit large variability in chemical signatures depending on the boundary layer histories. Western Europe frequently receives outflow from WCB originating over North America [Stohl, 2001]. For this region, Donnell et al. [2001] find that advective large-scale transport in the warm conveyor belts is the major mechanism to transport air from the boundary layer to the free troposphere with convection and turbulent mixing playing lesser, although nonnegligible, roles. Esler et al. [2003] refine this result by differentiating between intense and relatively weak frontal activity: in intense surface low systems, the mixing between air masses is efficient, whereas weaker surface low systems produce complex layered structure with significant transport in the stably stratified warm conveyor belt. Wild and Akimoto [2001] reach the same conclusion as Donnell et al. [2001] showing that between February and May over East Asia, the contributions of nonconvective vertical transport exceed convection. It is worth noting, however, that these two studies are based on large-scale CTM models and monthly average fluxes. Even if convection is not found predominant on a monthly mean basis, its impact on intercontinental transport during specific episodes can still be great. Unlike Europe, deep convective events are more frequent and vigorous over the Asian continent. Stohl et al. [2002] demonstrate that Asia tracer experience the strongest vertical transport of all the northern hemisphere continent. This lifting of pollution into the free troposphere is a strong condition for transpacific transport by westerly winds [Bey et al., 2001]. Indeed, the efficiency of the lifting to the free and upper troposphere condition the zonal and meridional transport across the ocean. This meteorological condition, however, is not always sufficient and the conditions favorable for the large-scale export are not so often encountered in East Asia. A study of winter storm tracks over the northern hemisphere showed that very few synoptic systems can be tracked across the width of the Pacific basin [Hoskins and Hodges, 2002]. Most of the systems generated over eastern Asia do not even reach the mid-Pacific. This condition, however, might not be necessary for the intercontinental transport of Asian pollution. Emissions from the Asian boundary layer can be transported over large distance by flows associated with the warm conveyor belt, which turns anticyclonically away from the parent low pressure [Hess and Vukicevic, 2003].

[4] The Transport and Chemical Evolution Over the Pacific (TRACE-P) aircraft mission was conducted over the western Pacific rim during March-April 2001 [Jacob et al., 2003]. The data from TRACE-P provide valuable constraints with which to test our understanding of the mechanisms controlling intercontinental transport of pollution into the Pacific. In this study, we focus on two cyclonic storms sampled during the second half of the TRACE-P mission. We show how these cyclonic systems have impacted the export of pollution out of the Asian continent. In particular, we focus on the relative role of rapid ventilation of pollutants by convection versus the slantwise slower ascent in the warm conveyor belts branch associated with the cyclones during these two episodes. To achieve this goal, we use a mesoscale three-dimensional model to examine the evolution of Asian outflow over the western Pacific through simulations of the TRACE-P local flights 13 and 15 out of Yokota.

\section{Aircraft Instrumentation and Methodology}

[5] Aircraft measurements are obtained by the NASA/ DC-8 during the TRACE-P campaign in March 2001. CO is measured using a diode laser in situ method. The instrument achieved a precision of $1 \mathrm{ppbv}$ for an integration time of $1 \mathrm{~s}$ [Sachse et al., 1987]. The study of the rising air defining the WCBs is made assuming that the wet bulb potential temperature $\left(\theta_{\mathrm{w}}\right)$ is a conserved property of the flow [Harrold, 1973]. $\theta_{\mathrm{w}}$ is a relatively conservative property within any one air mass during both dry and moist adiabatic processes. $\theta_{\mathrm{w}}$ is attained when a parcel is brought down to $1000 \mathrm{mb}$ from its lifting condensation level along a pseudoadiabat. Previous studies have found that $\theta_{\mathrm{w}}$ is a more effective signature of the origin of boundary layer air than equivalent potential temperature, virtual potential tempera- 
ture or relative humidity [Sturman and McGowan, 1995; Bethan et al., 1998]. In this work, $\theta_{\mathrm{w}}$ is derived from the temperature and the water vapor mixing ratio by applying formulae from Bolton [1980] for both model and observations. The warm conveyor belt (warm and humid air) is defined by high- $\theta_{\mathrm{w}}$ air that comes off from the base of the main warm sector, travels in the boundary layer back towards the cyclone center and then ascends above the cold conveyor belt.

[6] Carbon monoxide is a suitable tracer for large-scale transport because of its moderately long lifetime (13 months) in the atmosphere at midlatitude. $\mathrm{CO}$ is a good proxy of pollution from urban, industrialized areas and biomass burning. In this study, a CO tracer is introduced into the model to mimic carbon monoxide. The tracer has the same emission sources than $\mathrm{CO}$ but does not undergo chemical reactions, has no secondary source from the oxidation of methane or nonmethane hydrocarbons and no deposition loss.

\section{Model Description}

[7] The model used in this study is a nonhydrostatic mesoscale meteorological model, Meso-NH. A detailed description of the dynamics and chemistry of the model can be found in the literature [Lafore et al., 1994; Mari et al., 1999; Suhre et al., 2000; Tulet et al., 2003] (http:// www.aero.obs-mip.fr). Model horizontal resolution is $75 \mathrm{~km}$ by $75 \mathrm{~km}$. The vertical resolution is $50 \mathrm{~m}$ in the boundary layer and 400 in the free troposphere up to $20 \mathrm{~km}$, with a total of 72 levels. The dynamical timestep is $60 \mathrm{~s}$. The largescale forcing of dynamical parameters is provided by the European Centre for Medium-Range Weather Forecasts analysis every 6 hours. For flight 13 the simulation starts on 19 March 2001 at 0000 UTC and ends on 21 March 2001 at 1200 UTC. For flight 15 the simulation starts on 25 March 2001 at 0000 UTC and ends on 27 March 2001 at 1200 UTC

[8] The CO tracer is coupled on-line with the transport schemes in the model (advection, convection, turbulent mixing). Initialization and boundary conditions of carbon monoxide are provided by the GEOS-CHEM chemical transport model [Bey et al., 2001] for the TRACE-P meteorological period. Carbon monoxide from both fossil, biofuel and biomass burning are taken from the EDGAR v2.0 inventory based on year 1995 .

[9] A method of tracking coherent Lagrangian air masses has been implemented in the mesoscale model by Gheusi and Stein [2002]. It is based on three Eulerian passive tracers initialized with the coordinates of each grid cell. This "initial coordinates" method allows the later unambiguous identification of each Lagrangian air parcel by referring to its initial position. Further, the method allows the physical history of each parcel to be retrieved. In particular, rising flow associated with the WCBs are easily recognized as will be shown in the following sections.

\section{DC-8 Flight 13: Yokota Local 1}

\subsection{Synoptic Situation}

[10] The satellite image in Figure 1 shows the position of the cloud band associated with the cold front during flight

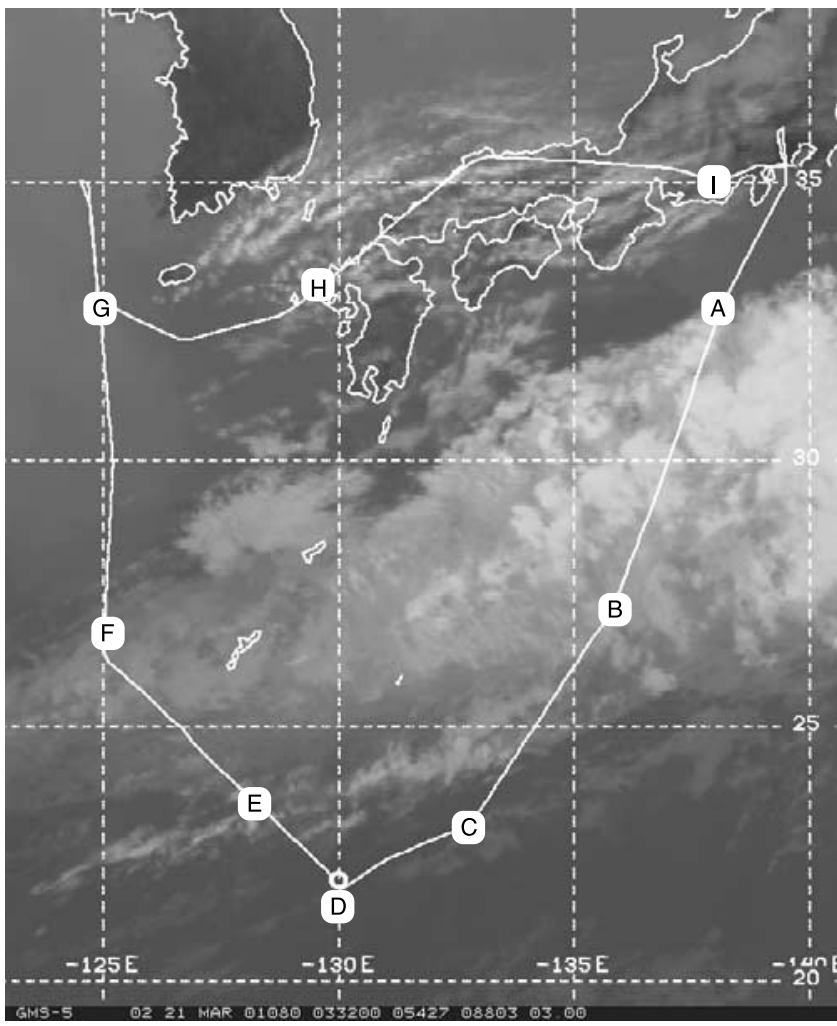

Figure 1. GMS-5 infrared satellite image for 20 March at 2300 UTC with track of flight 13 during the TRACE-P experiment. Flight 13 started on 20 March at 2250 UTC from Yokota returning on 21 March at 0825 UTC.

13. Flight 13 started on 20 March at 2250 UTC, from Yokota returning on 21 March at 0825 UTC. The aircraft flew from Yokota southwest to cross the cold front (segment A-D), then flew northwest to $\left(30^{\circ} \mathrm{N}, 125^{\circ} \mathrm{E}\right)$ recrossing the front (segment D-G). The aircraft then sampled polluted air in the low troposphere into the Yellow Sea. On the return leg to Yokota the aircraft climbed up to $200 \mathrm{hPa}$ to sample a stratospheric intrusion associated with the subtropical jet stream (segment H-I).

[11] In Figure 2, associated with the cold front identified in Figure 1, a low-pressure area is centered at $50^{\circ} \mathrm{N}-$ $145^{\circ} \mathrm{E}$, over the extreme northern Japan. A developing low-pressure area is located over northeastern Asia $\left(45^{\circ} \mathrm{N}\right.$, $\left.115^{\circ} \mathrm{E}\right)$. The simulated wet-bulb potential temperature at $700 \mathrm{hPa}$ marks the cold front extending from the low pressure system over Japan toward the southeast along $155^{\circ} \mathrm{E}$ and then southwest toward Taiwan. In cold fronts originating from Asia, the position of the WCB depends strongly on the location of the Japan jet and the flow is accelerated in the straight narrow band between the Aleutian Low and the Pacific High [Fuelberg et al., 2003]. The subtropical jet stream is oriented south of Japan. North of $40^{\circ} \mathrm{N}$, the cold front is associated with a dry intrusion characterized by elevated values of potential vorticity at $310 \mathrm{~K}$.

\subsection{Aircraft Observations and Model Analysis}

[12] Figure 3 shows the comparison between model results and aircraft observations along the flight track. 


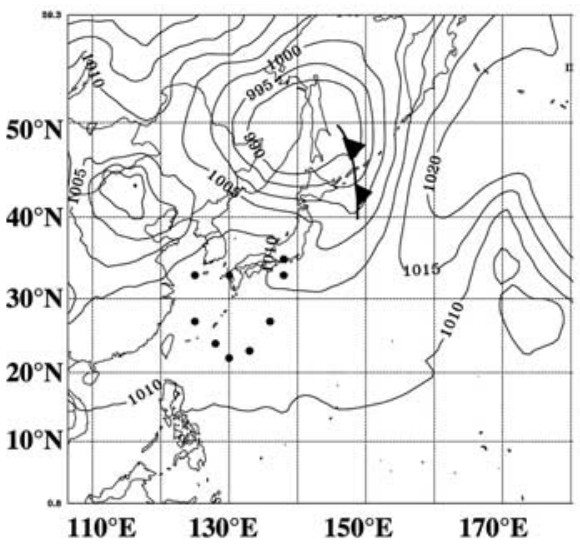

(a)

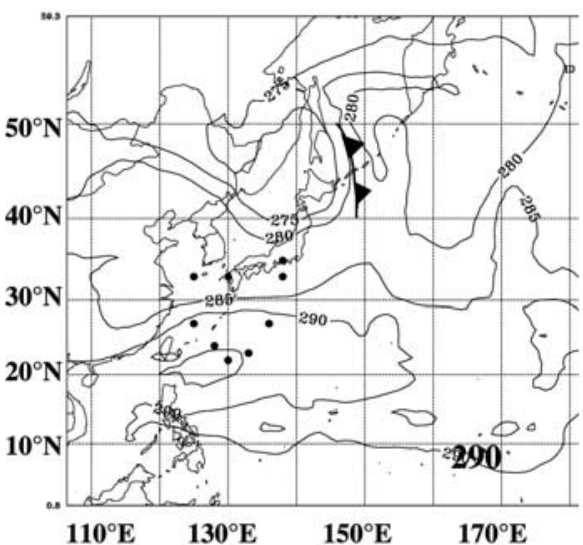

(c)

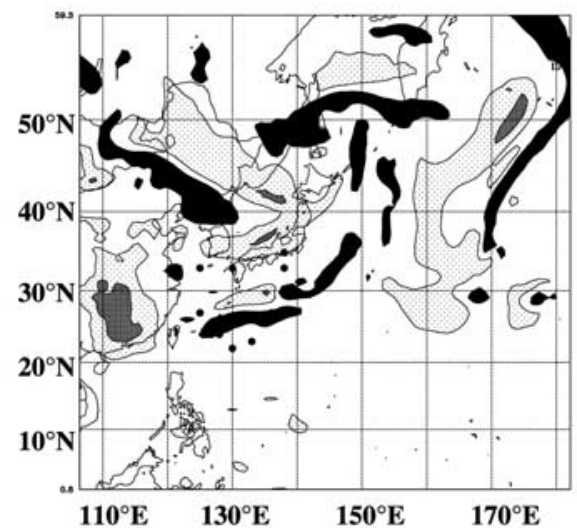

(e)

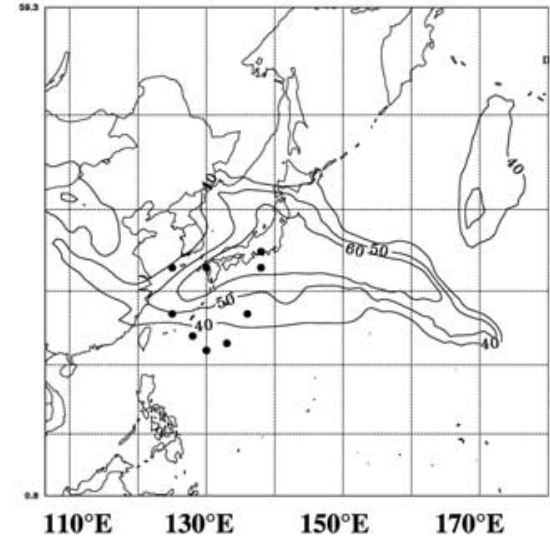

(b)

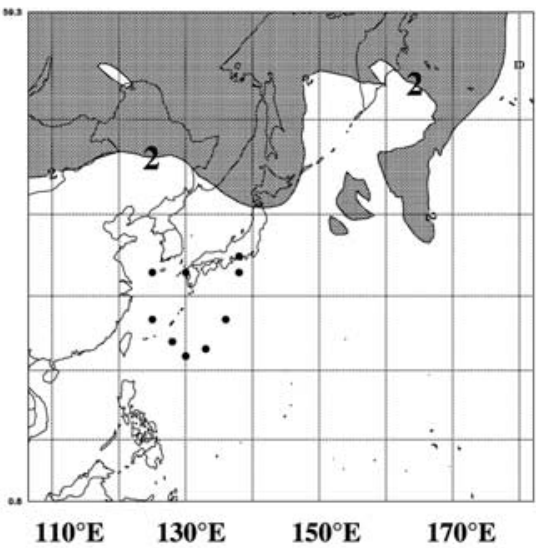

(d)

Figure 2. Simulated meteorology on 21 March at $00 \mathrm{~h} 00$ UTC: (a) mean sea level pressure in hPa, (b) subtropical jet stream at $330 \mathrm{~K}$, in $\mathrm{m} / \mathrm{s}$, (c) wet bulb potential temperature at $700 \mathrm{hPa}$, in $\mathrm{K}$, (d) potential vorticity at $310 \mathrm{~K}$, in PVU, and (e) initial altitude of air parcels present at $2000 \mathrm{~m}$ (about $800 \mathrm{hPa}$ ), after a 12-hour model run. Parcels with initial altitude below $1200 \mathrm{~m}$, which experienced ascending motion, are shaded in black color. Dotted regions indicate parcels having initial altitude above $2800 \mathrm{~m}$, and which have experienced descending motion.

Meteorological parameters such as wind speed, water vapor mixing ratios and wet bulb potential temperature are remarkably well represented by the model. The model captures respectively $95 \%, 86 \%$ and $96 \%$ of the observed variances in wind speed, water vapor and wet bulb potential temperature with median ratio of simulated-to-observed values of $1.07,0.57$ and 1.00 , respectively. The model captures $46 \%$ of the observed $\mathrm{CO}$ mixing ratio variance and the median ratio of simulated-to-observed $\mathrm{CO}$ mixing ratio is 1.44 . Below $800 \mathrm{hPa}$ (respectively above $300 \mathrm{hPa}$ ) the model captures $28 \%$ (respectively $86 \%$ ) of the observed $\mathrm{CO}$ mixing ratio variance. 

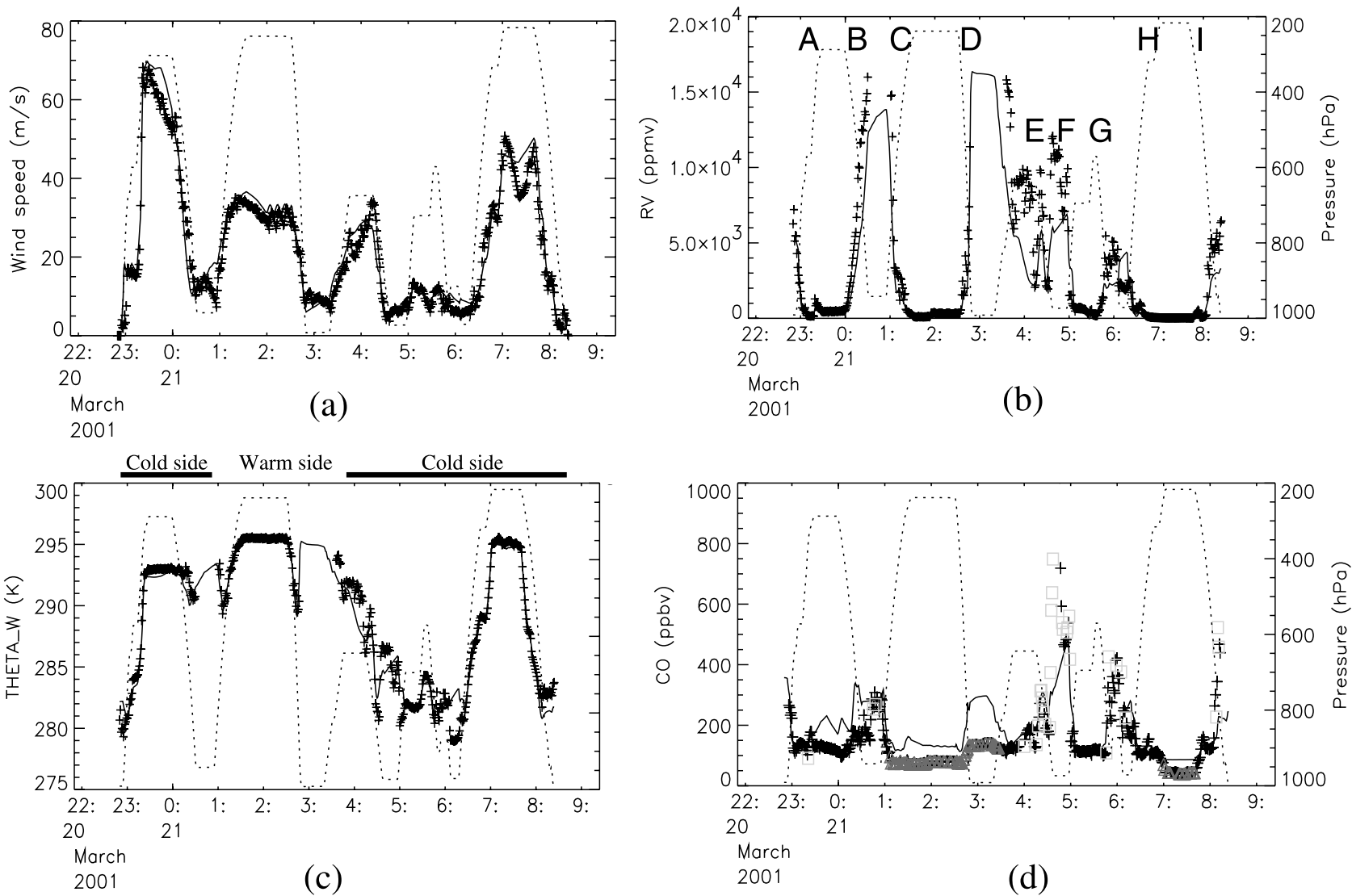

Figure 3. Simulated (solid line) and observed (crosses) values over the entire duration of flight 13 of (a) wind speed in $\mathrm{m} / \mathrm{s}$, (b) water vapor mixing ratio in ppmv, (c) wet bulb potential temperature in $\mathrm{K}$, and (d) $\mathrm{CO}$ in ppbv. $\mathrm{CO}$ observations where $\mathrm{C}_{2} \mathrm{H}_{2} / \mathrm{CO}>3\left(\mathrm{C}_{2} \mathrm{H}_{2} / \mathrm{CO}<1\right.$ are represented by squares (triangles). The dotted line represents the altitude of the flight in $\mathrm{hPa}$.

[13] Southwest of Yokota, upper tropospheric CO mixing ratios (segment $\mathrm{A}-\mathrm{B}$ ) ranged between 100 and $150 \mathrm{ppbv}$ for the observations, $200 \mathrm{ppbv}$ for the model. High wind speed (between 50 and $70 \mathrm{~m} / \mathrm{s}$ ) indicates air masses advected in the jet stream (Figure 3a). In Figure 4c the model shows a pollution plume, originating from Southeast Asia, moving northeast toward Japan, then turning clockwise toward subtropical latitudes. It is this upper tropospheric plume that is sampled during the first leg A-B.

[14] South of the cold front, in the marine boundary layer, relatively high CO mixing ratios (up to $300 \mathrm{ppbv}$ ) are both observed and simulated $1500 \mathrm{~km}$ away from the chinese coast (segment B-C). High $\theta_{\mathrm{w}}\left(290<\theta_{\mathrm{w}}<294 \mathrm{~K}\right)$ indicates that the aircraft is sampling air in the warm side of the cold

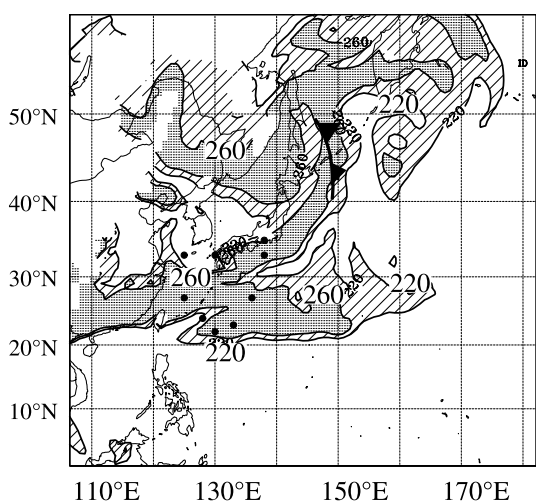

(a)

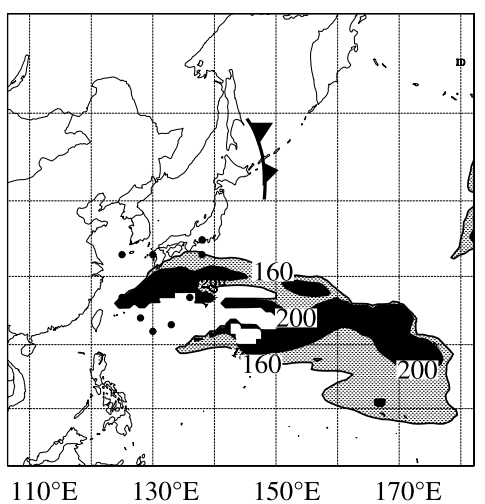

(b)

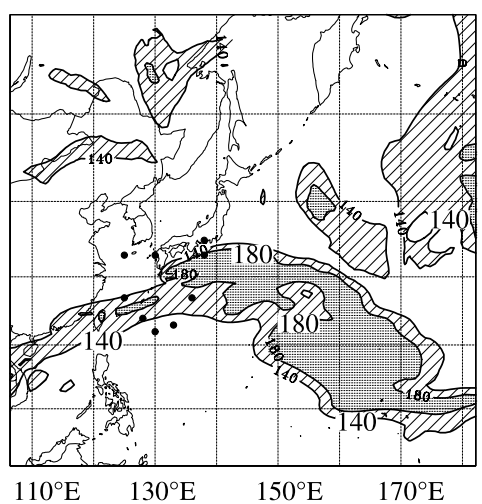

(c)

Figure 4. Simulated CO tracer, in ppbv, on 21 March 2001 at $0000 \mathrm{UTC}$ (a) at $900 \mathrm{hPa}$, (b) on the $291 \mathrm{~K}$ wet-bulb potential temperature surface, and (c) at $300 \mathrm{hPa}$. 
front. In Figure 3d, observations are labeled according to the ratio between ethyne and $\mathrm{CO}$. The ratio $\mathrm{C}_{2} \mathrm{H}_{2} / \mathrm{CO}$ indicates the "chemical" age of the sampled air mass [Gregory et al., 1997]. $\mathrm{C}_{2} \mathrm{H}_{2} / \mathrm{CO}<1$ is representative of emissions at least 5 days old, $\mathrm{C}_{2} \mathrm{H}_{2} / \mathrm{CO}>3$ can be interpreted as freshly emitted air masses (less than 1 day). During the boundary layer leg, the $\mathrm{C}_{2} \mathrm{H}_{2} / \mathrm{CO}$ ratio is close to 3 indicating a relatively young air mass. In Figure $4 \mathrm{a}$ the model shows this polluted plume at $900 \mathrm{hPa}$, extending zonally toward the ocean and guided in the $20-30^{\circ} \mathrm{N}$ latitudinal band. The origin of this air mass is discussed in more details in section 6 .

[15] The air sampled during the upper tropospheric southernmost leg (segment C-D) is relatively clean $(\mathrm{CO}<$ $150 \mathrm{ppbv}$ for both model and observations). Low $\mathrm{C}_{2} \mathrm{H}_{2} / \mathrm{CO}$ indicates aged air mass. Figure $4 \mathrm{c}$ indicates that the aircraft is located south of the polluted plume from Southeast Asia at $300 \mathrm{hPa}$ which explains why the $\mathrm{CO}$ mixing ratios are lower during this leg compared to leg A-B.

[16] When the aircraft moved northward (segment E-F in Figure 3), it recrossed the cold front in the lower troposphere $(750 \mathrm{hPa})$. Both the model and the observations show a strong gradient in $\mathrm{CO}$ mixing ratios (increasing from 150 to $250 \mathrm{ppbv}$ ) and $\theta_{\mathrm{w}}$ (decreasing from 292 down to $286 \mathrm{~K}$ ). At the same time, the ratio $\mathrm{C}_{2} \mathrm{H}_{2} / \mathrm{CO}$ increases from 1.5 in the warm side of the cold front to 3.5 in the cold side of the cold front, indicating fresh emissions.

[17] The aircraft remained in the cold side of the cold front until the end of the flight. As the aircraft flew over the Yellow Sea (segment F-H in Figures 1 and 4), very high pollution from Shanghai is sampled [Simpson et al., 2003; Talbot et al., 2003; Vay et al., 2003]. The model simulates the increase in $\mathrm{CO}$ mixing ratios but underestimate by a factor of 2 to 3 the observed mixing ratios in the plume. Low values of $\theta_{\mathrm{w}}\left(278<\theta_{\mathrm{w}}<286 \mathrm{~K}\right)$, high observed $\mathrm{C}_{2} \mathrm{H}_{2} /$ $\mathrm{CO}$ ratios and $\mathrm{CO}$ mixing ratios (up to $1000 \mathrm{ppbv}$ for the observations, up to $500 \mathrm{ppbv}$ for the model) all identify freshly emitted pollution trapped in the cold side of the cold front above the Yellow Sea (segment F-G-H). The low simulated CO concentrations in the Shanghai plume compared to the observations may be due to an underestimation of the Asian sources as demonstrated by Palmer et al. [2003].

[18] On the return leg in the upper troposphere $(200 \mathrm{hPa})$, the major meteorological feature is the Japan jet stream. Both model and observations show minima in CO mixing ratios (50 ppbv) These low CO mixing ratios are correlated with high ozone mixing ratios (200 ppbv, not show here) indicating a stratospheric origin of the sampled air mass.

\section{DC-8 Flight 15: Yokota Local 3}

\subsection{Synoptic Situation}

[19] Flight 15 took place 6 days after flight 13 in the same region. The flight started on 26 March at 2330 UTC, from Yokota returning on $27 \mathrm{March}$ at 0900 UTC. The aircraft conducted measurements along the Asian coast, one at $133^{\circ} \mathrm{E}-139^{\circ} \mathrm{E}$ (segment $\mathrm{A}-\mathrm{B}$ ) and one at $125^{\circ} \mathrm{E}$ (segment E-F) (Figure 5). The return leg to Yokota took place in the middle troposphere (segment G-K). As for flight 13, in Figure 6, a low-pressure area is centered at $45^{\circ} \mathrm{N}, 140^{\circ} \mathrm{E}$, over the extreme northern Japan. A surface cold front, characterized by a strong gradient of wet-bulb

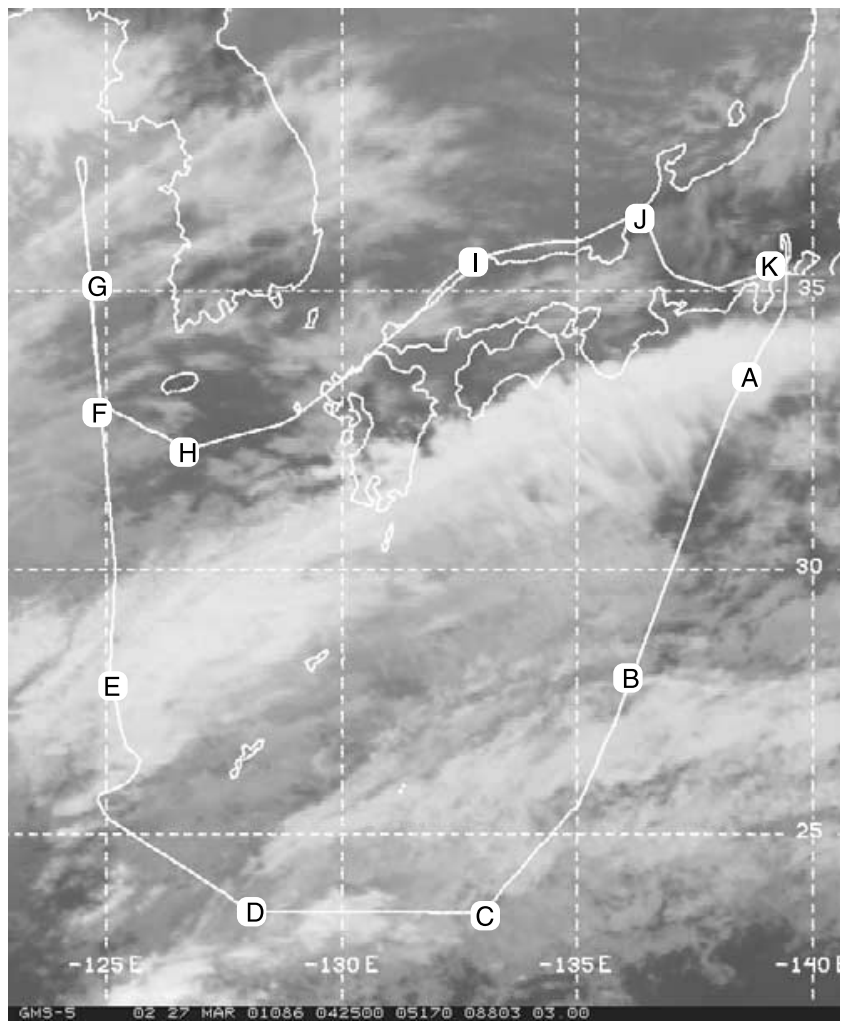

Figure 5. GMS-5 infrared satellite image for 26 March at 2330 UTC with track of flight 15 during the TRACE-P experiment. Flight 15 started on 26 March at 2330 UTC from Yokota returning on 27 March at 0900 UTC.

potential temperature, extended southeast to near $30^{\circ} \mathrm{N}-$ $150^{\circ} \mathrm{E}$ and then west to near Taiwan. In the upper troposphere, the jet stream has strengthened considerably just south of Japan compare to flight 13 . North of the jet, high positive values of potential vorticity signal a dry intrusion.

\subsection{Aircraft Observations and Model Analysis}

[20] Figure 7 shows the time series of observed and simulated meteorological parameters and $\mathrm{CO}$ along the flight track during flight 15 . Wind speed, water vapor mixing ratio and $\theta_{\mathrm{w}}$ are well simulated: the model captures respectively $95 \%, 91 \%$ and $97 \%$ of wind speed, water vapor mixing ratio and $\theta_{\mathrm{w}}$ observed variance. The median ratio of simulated-to-observed wind speed, water vapor mixing ratio and $\theta_{\mathrm{w}}$ are respectively $1.02,0.69$ and 1.00 . The model captures $28 \%$ of the observed $\mathrm{CO}$ mixing ratio variance and the median ratio of simulated-to-observed $\mathrm{CO}$ mixing ratio is 1.22 . Below $800 \mathrm{hPa}$ (respectively above $300 \mathrm{hPa}$ ) the model captures $27 \%$ (respectively $17 \%$ ) of the observed CO mixing ratio variance In Figure $7 \mathrm{~d}$ the model tends to overestimate the upper tropospheric $\mathrm{CO}$ mixing ratios sometimes by a factor of 2 but reproduces reasonably well the observed $\mathrm{CO}$ in the lower and mid-troposphere. One exception is the high level of pollution observed at takeoff and landing at the Yokota airport (around $600 \mathrm{ppbv}$ of CO for the observations, $300 \mathrm{ppbv}$ for the model). The underestimation of very polluted air masses close to the point sources reflects the dilution of the emission strength due to 


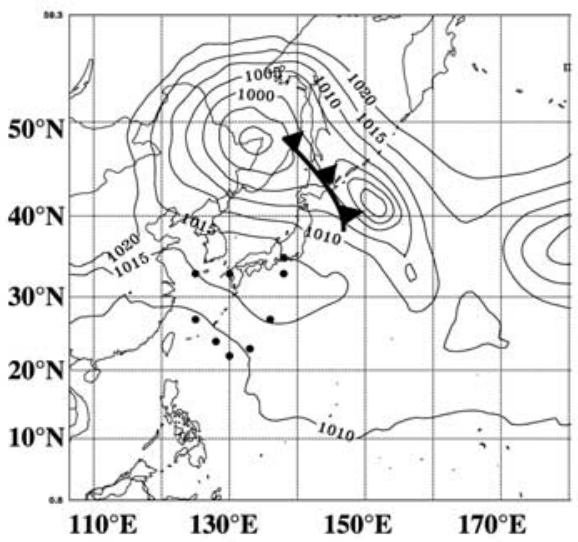

(a)

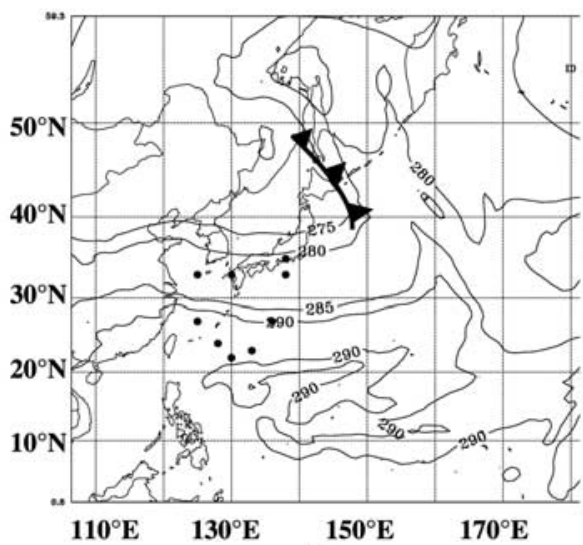

(c)

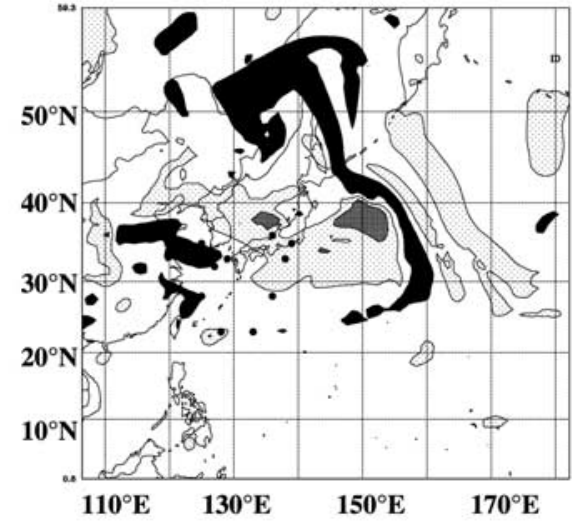

(e)

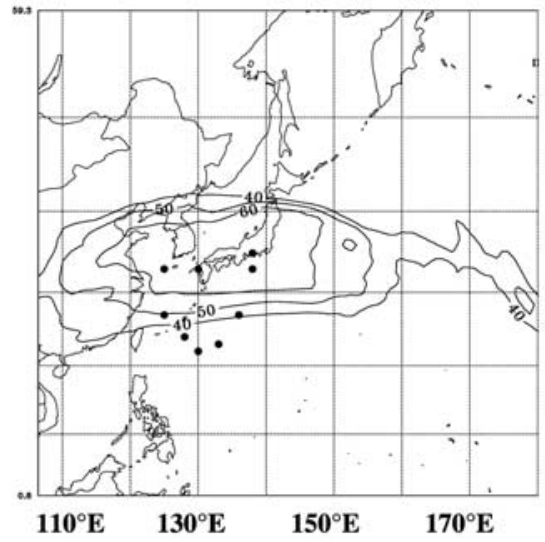

(b)

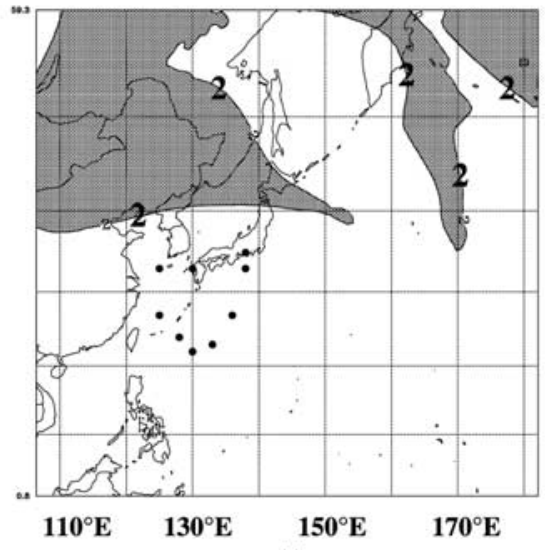

(d)

Figure 6. Simulated meteorology on 27 March at 00h00 UTC. (a) mean sea level pressure in hPa, (b) subtropical jet stream at $330 \mathrm{~K}$, in $\mathrm{m} / \mathrm{s}$, (c) wet bulb potential temperature at $700 \mathrm{hPa}$, in $\mathrm{K}$, (d) potential vorticity at $310 \mathrm{~K}$, in PVU, and (e) initial altitude of air parcels present at $2000 \mathrm{~m}(800 \mathrm{hPa})$, after a 12-hour model run. Ascending regions are shaded in black color; descending regions are dotted.

the horizontal resolution of the model and the possible underestimation of the emissions themselves [Palmer et al., 2003].

[21] During the two legs parallel to the Asian coast (segments A-B and E-F in Figures 5 and 7), the aircraft sampled upper tropospheric air in the jet stream (wind speed around $80 \mathrm{~m} / \mathrm{s}$ ). Observed $\mathrm{CO}$ mixing ratios are between
100 and $200 \mathrm{ppbv}$ (between 150 and $250 \mathrm{ppbv}$ for the model). During the upper tropospheric leg at $125^{\circ} \mathrm{E}, \mathrm{CO}$ mixing ratios dropped to $50 \mathrm{ppbv}$ and ozone increased to $200 \mathrm{ppbv}$, indicating a stratospheric origin of the sampled air mass. The wet-bulb potential temperature decreased from $293 \mathrm{~K}$ down to $290 \mathrm{~K}$ in both the model and the observations as the aircraft moved northward. Upper tropo- 

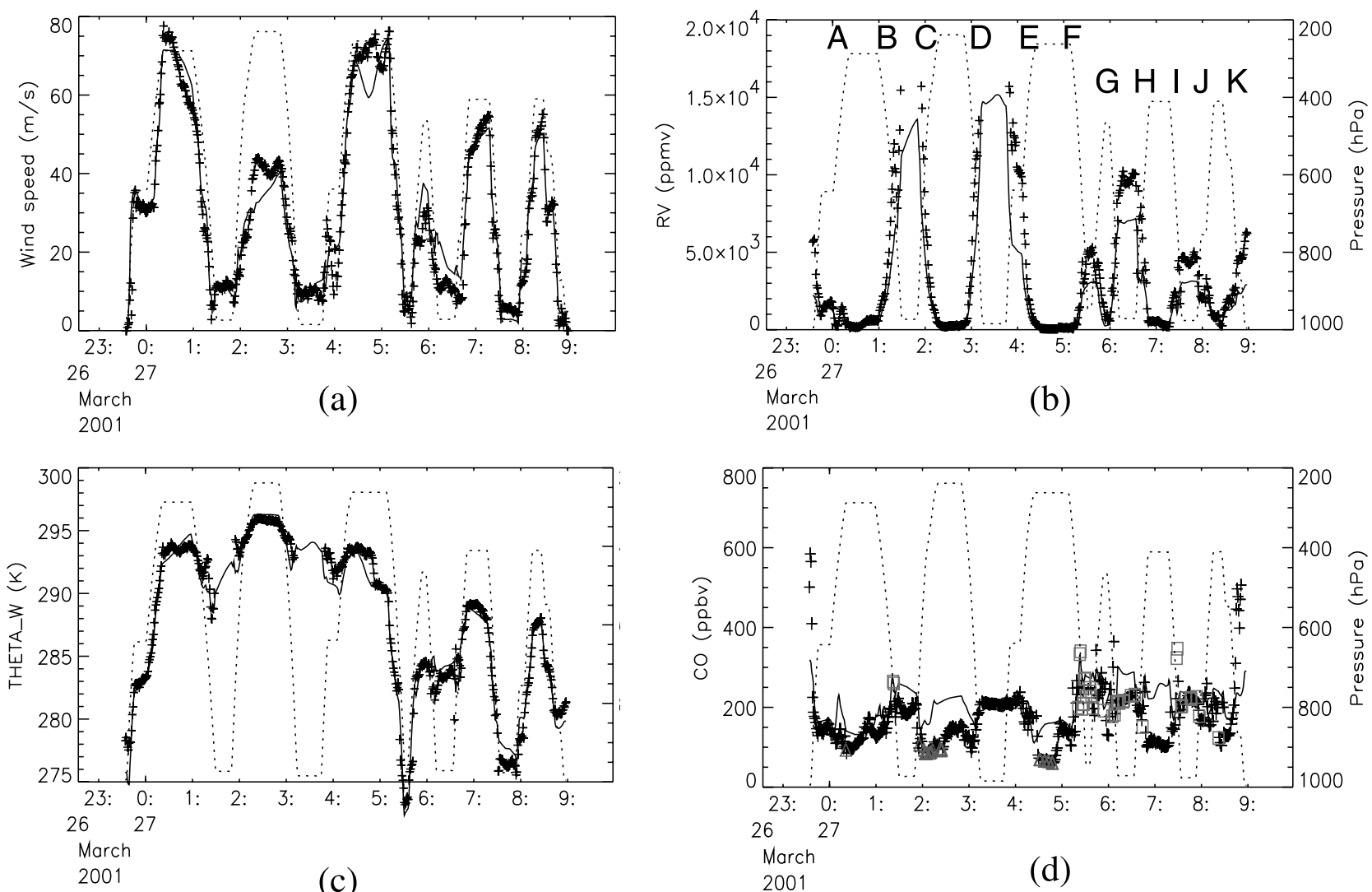

Figure 7. Same as Figure 3 for flight 15.

spheric air masses during both segments have a $\mathrm{C}_{2} \mathrm{H}_{2} / \mathrm{CO}$ ratio less than 1 , characterizing aged air masses. The southernmost upper tropospheric leg (segment C-D) is located south of the jet stream (wind speed around $40 \mathrm{~m} / \mathrm{s}$ ). The aircraft sampled air masses in the warm side of the cold front as derived from high wet-bulb potential temperature values (see also Figure $6 \mathrm{c}$ ) and with $\mathrm{C}_{2} \mathrm{H}_{2} / \mathrm{CO}$ values less than 1 representative of aged air masses.

[22] During the two sections in the boundary layer south of $30^{\circ} \mathrm{N}$ (segments B-C and D-E), the aircraft is in the warm side of the cold front $\left(\theta_{\mathrm{w}}>290 \mathrm{~K}\right)$ with $\mathrm{CO}$ mixing ratios around $200 \mathrm{ppbv}$ in the model and the observations. The air sampled in the boundary layer as the aircraft moved northward at latitudes higher than $33^{\circ} \mathrm{N}$ had complete different characteristics: the air is 2 to 3 times drier (Figure 7b), with lower $\theta_{\mathrm{w}}$ values (between 275 and $285 \mathrm{~K}$ ) and higher $\mathrm{CO}$ mixing ratios (from 200 to $600 \mathrm{ppbv}$ ). All observed and simulated parameters indicate air sampled in the cold and polluted boundary layer behind the cold front. The observed ratio $\mathrm{C}_{2} \mathrm{H}_{2} / \mathrm{CO}$ is higher than 3 for most of the measurements indicating fresh pollution. It is interesting to note that the observed and modeled $\mathrm{CO}$ mixing ratios are similar (around $200 \mathrm{ppbv}$ ) during the three legs in the boundary layer north of $30^{\circ} \mathrm{N}$ (segments F-G, G-H, I-J). During these segments, however, values of $\theta_{\mathrm{w}}$ are different and reveal that the origin of these air masses is different. At latitude higher than $33^{\circ} \mathrm{N}$ (segments F-G and I-J), $\theta_{\mathrm{w}}<$ $280 \mathrm{~K}$ (Figure 7c) and the air is subsiding (Figure 6e), characterizing the rear of the cold front. At latitude lower than $33^{\circ} \mathrm{N}$ (segment $\mathrm{G}-\mathrm{H}$ ), the nearest leg from the china coast is characterized by higher $\theta_{\mathrm{w}}(>280 \mathrm{~K})$ and ascending air related to convection as will be discussed in the following section.

\section{Export of Asian Pollution During the Two Cold Front Episodes}

[23] The analysis described above shows that the model captures the features observed in both the meteorological (wind speed, water vapor, $\theta_{\mathrm{w}}$ ) and chemical $(\mathrm{CO})$ parameters. The model seems to capture especially well the various airstreams associated with these cyclonic systems. We can therefore use the model to give insight into the meteorological processes driving the export of pollutants from the continental regions into the remote ocean region by these cyclonic systems. The model can be used to interpret the aircraft measurements, provide a three-dimensional picture of the two meteorological episodes and give some insights on what had happened in the remote ocean during these two episodes and for which no measurements are available. In the following, the focus is on the processes in the lower, mid and upper troposphere and how similar or different they are between the two flights.

[24] In the upper troposphere (Figures 4c, 8a, 9a, and 10c), convective lifting of Southeast Asian biomass burning [Folkins et al., 1997; Bey et al., 2001] is responsible for the large plumes of pollution during both episodes. At this high latitude the westward offshore flow is predominant, turning anticyclonically over the ocean. The upper tropospheric plume takes a well marked anticyclonic curve. It is worth 


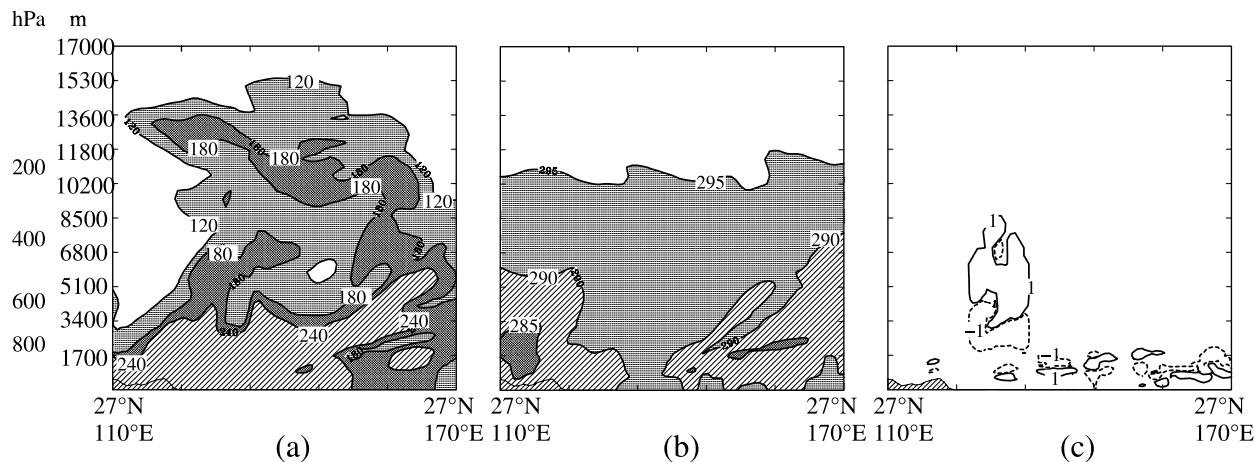

Figure 8. Simulated longitudinal cross sections at $27^{\circ} \mathrm{N}$ from 110 to $170^{\circ} \mathrm{E}$, on 21 March 2001 at 0000 UTC for (a) CO tracer in ppbv, (b) wet-bulb potential temperature, in $\mathrm{K}$, and (c) convective source term for $\mathrm{CO}$ in $\mathrm{ppbv} / \mathrm{h}$.

noting that convection during flight 15 is more active over Southeast Asia and south China than during flight 13. In the upper troposphere, the pollution plume is broader and the $\mathrm{CO}$ column concentration is twice as large as during flight 13 in the plume.

[25] During flight 13, two plumes of pollution come out in the boundary layer (Figure 4a). The pollution from Japan and north of China is confined to the cold side of the cold front and has a cyclonic signature. Both the model and the observations show high values of $\mathrm{CO}$ in the cold boundary layer (Figures 3 and $4 \mathrm{a}$ ). This result is consistent with the postfrontal boundary layer outflow described by Bey et al. [2001] and Liu et al. [2003]. A second boundary layer plume emerges below $30^{\circ} \mathrm{N}$ from the emissions of China and Southeast Asia. This plume undergoes an offshore zonal flow in the warm boundary layer in the $20-30^{\circ} \mathrm{N}$ latitude band (Figures $4 \mathrm{a}$ and $4 \mathrm{~b}$ ). This is the plume that has been observed by the aircraft while descending southward after crossing the cold front (see section 4). Unlike the $\mathrm{CO}$ plume behind the cold front, the southernmost plume on the warm side of the cold front has a large vertical extension up to $500 \mathrm{hPa}$. The plume is collocated with the ascending airstream between 120 and $140^{\circ} \mathrm{E}$ in Figure 2e.

[26] This figure shows the initial altitude of air parcels that reached $2000 \mathrm{~m}(800 \mathrm{hPa})$ after a 12-hour model run. The warm conveyor belt is apparent as a narrow airstream of rising air parcels (i.e., parcels that are initially below $2000 \mathrm{~m}$ ) with a northward cyclonic curve. In the warm conveyor belt, parcels have raised from $600 \mathrm{~m}$ to $2000 \mathrm{~m}$ in 12 hours, which corresponds approximately to $100 \mathrm{~m} / \mathrm{h}$. Surprisingly, the southern CO plume on the $291 \mathrm{~K}$ wet bulb potential temperature surface does not follow the same cyclonic pathway (Figure 4b). Instead, the polluted plume follows a curved clockwise path and leaves the northern part of the warm conveyor belt relatively clean. The longitudinal cross section at $27^{\circ} \mathrm{N}$ in Figure 8 helps to understand why the pollution plume that is initially following the nascent warm conveyor belt near the continent changes to an anticyclonical route. As the pollution moves out of the Chinese coast, it is efficiently mixed and lifted by intensive convection up to $9 \mathrm{~km}$. The convective source for $\mathrm{CO}$ exceeds $7 \mathrm{ppbv} / \mathrm{h}$ in the $5-9 \mathrm{~km}$ altitude range. Above $700 \mathrm{hPa}$ (3 km), pronounced anticyclonic circulation has developed in the $20-30^{\circ} \mathrm{N}$ latitudinal band [Fuelberg et al., 2003] during the second half of the experiment. As a main consequence, the pollution uplifted at this altitude by the convection takes a different path compared to the cyclonic track. Because of the efficient ventilation of the warm conveyor belt by convection, less pollution is available to undergo the slower slantwise vertical motion associated with the warm conveyor belt branch. The model shows that the WCB stayed relatively clean although no observations are available in the remote mid-Pacific to confirm this finding.

[27] The latitudinal cross section in Figure 9 illustrates the interleaving of the air masses of different origin. The cold front acts as a boundary between pollution from Russia in

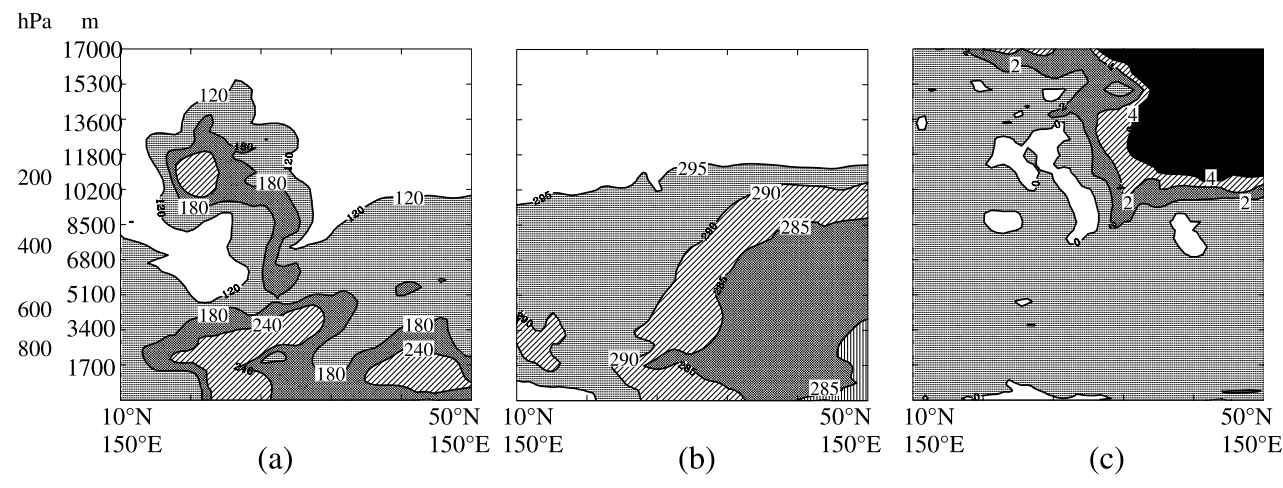

Figure 9. Simulated latitudinal cross sections at $150^{\circ} \mathrm{E}$ from 10 to $50^{\circ} \mathrm{N}$, on $21 \mathrm{March} 2001$ at $0000 \mathrm{UTC}$ for (a) $\mathrm{CO}$ tracer in ppbv, (b) wet-bulb potential temperature, in $\mathrm{K}$, and (c) potential vorticity (PVU). 


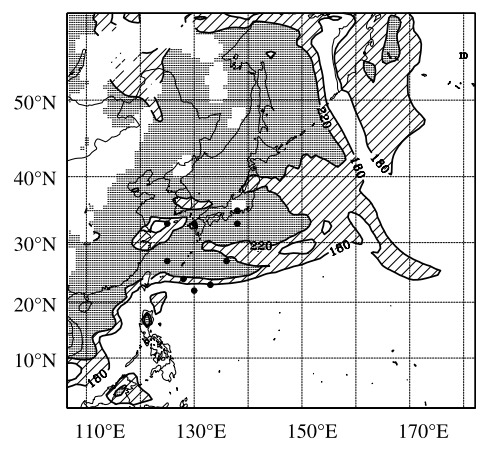

(a)

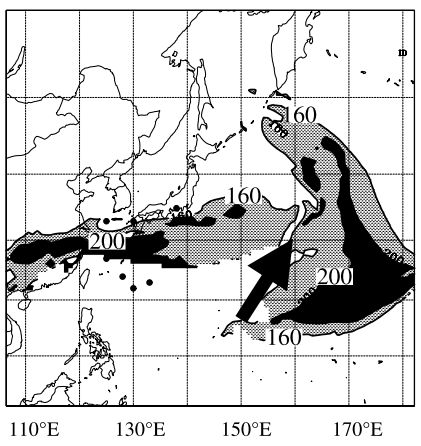

(b)

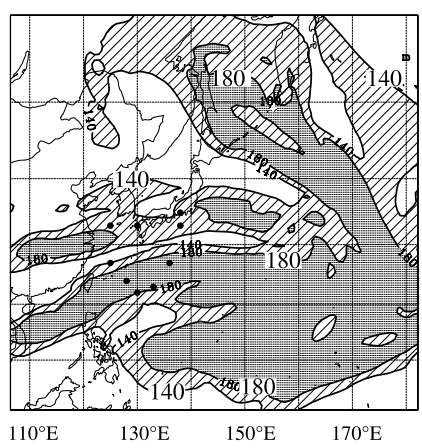

(c)

Figure 10. Simulated CO tracer, in ppbv, on 27 March 2001 at $0000 \mathrm{UTC}$ (a) at $900 \mathrm{hPa}$, (b) on the $290 \mathrm{~K}$ wet-bulb potential temperature surface, and (c) at $300 \mathrm{hPa}$. The arrow indicates the position of the warm conveyor belt.

the cold boundary layer and pollution from east China in the warm boundary layer. In the upper troposphere the subtropical jet separates the tropospheric air south of the jet from stratospheric air north of the jet.

[28] On 27 March at 0000 UTC the warm conveyor belt associated with the cyclonic system north of Japan has already moved to the remote ocean at $150-160^{\circ} \mathrm{E}$ (Figure 6e). The flight took place in a region of strong latitudinal gradient of $\theta_{\mathrm{w}}$ (Figure 6c) which is well documented by both the model and the observations (see section 5). Both the model and the observations indicate that the export in the boundary layer is not as efficient as during flight 13 during which the warm conveyor belt and subsequent ascending flow are closer to the continent (Figures $7 \mathrm{~d}$ and 10a). In particular, the observations during flight 13 show a clear spatial gradient of $\mathrm{CO}$ concentrations in the boundary layer (Figure $3 \mathrm{~d})$ due to the advected polluted plume whereas during flight 15 the $\mathrm{CO}$ mixing ratios in the boundary layer are always around $200 \mathrm{ppbv}$ (Figure 7d). Ascending motions are simulated over the northern chinese coast in the $30-$ $40^{\circ} \mathrm{N}$ and $110-130^{\circ} \mathrm{E}$ region in Figure 6e which are not connected to the warm conveyor belt branch. Figure 11 indicates that these bubbles of ascending air are due to convection over the continent. As during flight 13, this convection rapidly brings the $\mathrm{CO}$ tracer above $700 \mathrm{hPa}$ where it can experience offshore advection (Figure 10b).
[29] Figure 11 shows the fate of this pollution plume as it moves over the remote ocean during flight 15 . The model shows a warm conveyor belt bringing poor-CO air masses upward ahead of the cold front, before ascending above the warm front (Figures 11a and 11b). The model also shows that this ascending motion in the warm conveyor belt is associated with oceanic deep convection which acts as a sink for CO (convective terms have negative values indicating decrease of $\mathrm{CO}$ by more than $1 \mathrm{ppbv} / \mathrm{h}$ ). The clean warm conveyor belt traveling in the boundary layer back towards the cyclone center and the oceanic convection both split the polluted plume in the middle and upper troposphere (Figures 10b and 12).

[30] From the above discussion, it is clear that the meteorological conditions during flight 13 and 15 are not totally favorable for the intercontinental transport of undiluted pollution over the Pacific Ocean in the low and middle troposphere. During both flights, intense cyclones are located north of Japan with their associated warm conveyor belts and the continental emissions experience strong lifting by convection near the Chinese coast. Because of this strong ventilation, the pollution is transported at high altitude more efficiently than in the warm conveyor belts. During flight 13 , once above $700 \mathrm{hPa}(3 \mathrm{~km})$, the pollution flows anticyclonically toward the persistent Pacific high, leaving the warm conveyor belt relatively free of pollution. During

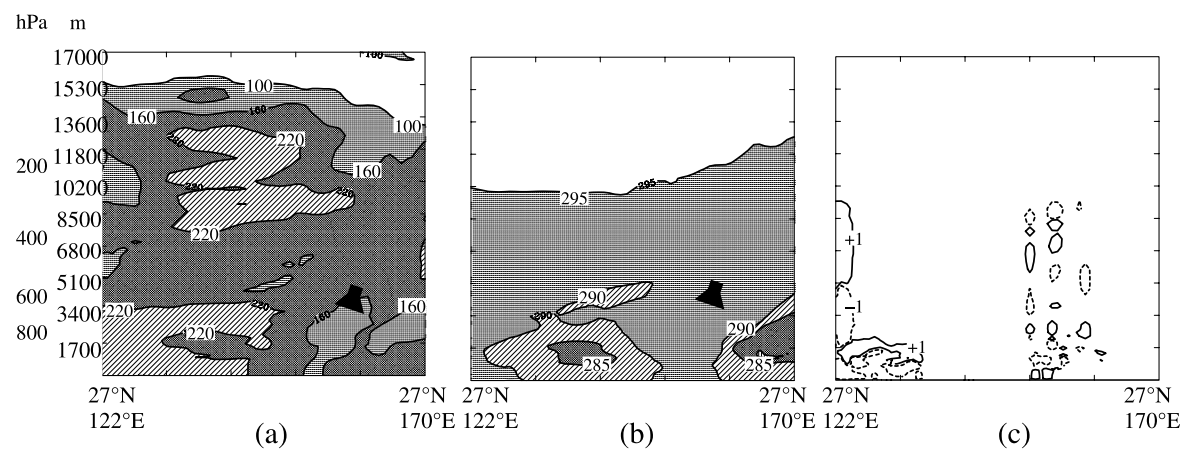

Figure 11. Simulated longitudinal cross sections at $27^{\circ} \mathrm{N}$ from 122 to $170^{\circ} \mathrm{E}$, on 27 March 2001 at 0000 UTC for (a) CO tracer in ppbv, (b) wet-bulb potential temperature, in K, and (c) convective source term for $\mathrm{CO}$ in $\mathrm{ppbv} / \mathrm{h}$. The arrow indicates the position of the warm conveyor belt. 


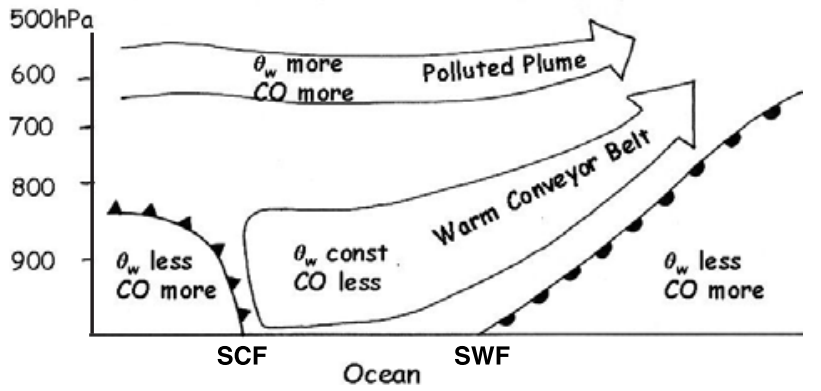

Figure 12. Schematic diagram of the warm conveyor belt in a vertical cross section across the cold and warm fronts (redrawn from Harrold [1973]) and how it splits the polluted plume over the ocean during flight 15. SCF, Surface Cold Front; SWF, Surface Warm Front.

flight 15 , lifting of the continental pollution to the free troposphere is followed by a zonal advection in the 20 $30^{\circ} \mathrm{N}$ latitude band. When the flight starts, the warm conveyor belt is already in the remote ocean lifting clean air from the ocean. As a consequence, around $150^{\circ} \mathrm{E}$, the clean rising air associated with the WCB and oceanic convection splits the polluted plume in the free troposphere, favoring the dilution of the plume advected toward the Pacific Ocean.

\section{Conclusions}

[31] Two cold front episodes are sampled during two flights out of Yokota, Japan, during the TRACE-P mission. The aircraft remains south of the cyclonic centers and crosses the cold fronts at several occurrences, giving the opportunity to characterize very distinct air masses.

[32] In the upper troposphere and during both flights, a large plume of CO from Southeast Asia is both observed and modeled south of the subtropical jetstream. The polluted plume clearly shows an anticyclonical curved motion induced by the Pacific high. North of the jet, air is relatively clean of $\mathrm{CO}$ pollution and propitious to stratospheric intrusions.

[33] Very polluted and freshly emitted pollution is observed and simulated in the cold boundary layer in the rear of the cold front during both flights. This pollution is trapped in the boundary layer by the synoptic subsidence behind the cold front. During flight 13, the warm conveyor belt associated with the cyclonic system originates from the eastern seaboard of China near the pollution sources. The strong convection simulated near the chinese coast efficiently mix and lift the emissions above $500 \mathrm{hPa}$. At this altitude the mean flow has a well marked anticyclonical signature. As a result, the pollution plume ends with a different route than the cyclonic northward ascending motion. Consequently, the northeastern part of the warm conveyor belt is found relatively free of pollution although no aircraft observations are available to confirm this point. Thus although the necessary meteorological conditions for an efficient export of pollution are met during flight 13 (i.e., the occurrences of the warm conveyor belt and deep convection near the source regions), no significant pollution is simulated in the mid-Pacific in the lower and middle troposphere. The efficient ventilation of the WCB by convection near the coast, the advection by the anticyclonical flow above $700 \mathrm{hPa}$ and the downward motion associated with the Pacific high in the remote ocean significantly prevent any long-range transport of undiluted pollution in the WCB.

[34] During flight 15, the conveyor belts have already moved to the remote ocean. Convective upward transport is simulated over the source regions between 20 and $40^{\circ} \mathrm{N}$. This lifting is followed by a zonal advection offshore in the middle troposphere. The polluted plume stretches up to $150^{\circ} \mathrm{E}$. At this longitude, the plume is split by the rising air in the warm conveyor belt which transports CO-poor air northward and by the oceanic convection which transports clean air masses upward. These mechanisms lead to the dilution of Asian pollution in WCB en route to North America and add to the episodic nature of the Asian outflow by fragmenting the pollution plume. Future works are needed to understand the impact of these clean warm conveyor belts and oceanic convection on the secondary pollutant generation occurring en route and the behavior of insoluble and soluble chemical species other than carbon monoxide.

[35] Acknowledgments. This work was supported by NASA funding at the University of Harvard and the French Programme National de Chimie Atmospherique (CNRS). Computational resources were provided by the Institut for Development and Resources in Intensive Scientific computing. The authors want to thank the three anonymous reviewers for their useful comments

\section{References}

Berkowitz, C. M., P. H. Daum, C. W. Spicer, and M. Bussness (1996), Synoptic patterns associated with the flux of excess ozone to the western North Atlantic, J. Geophys. Res., 101, 2823-2893.

Bethan, S., G. Vaughan, C. Gerbig, A. Volz-Thomas, H. Richer, and D. A. Tiddeman (1998), Chemical air mass differences near fronts, J. Geophys. Res., 103, 13,413-13,434.

Bey, I., D. J. Jacob, J. A. Logan, and R. M. Yantosca (2001), Asian chemical outflow to the Pacific: Origins, pathways, and budgets, J. Geophys. Res., 106, 23,097-23,114.

Bolton, D. (1980), The computation of equivalent potential temperature, Mon. Weather Rev., 108, 1046-1053.

Browning, K. A., and B. W. Golding (1995), Mesoscale aspects of a dry intrusion within a vigorous cyclone, Q. J. R. Meteorol. Soc., 121, 463-493. Browning, K. A., and N. M. Roberts (1994), Structure of a frontal cyclone, O. J. R. Meteorol. Soc., 120, 1535-1557.

Collins, W. J., D. S. Stevenson, C. E. Johnson, and R. G. Derwent (1999), Role of convectionin determining the budget of odd hydrogen in the upper troposphere, J. Geophys. Res., 104, 26,927-26,941.

Cooper, O. R., J. L. Moody, D. D. Parrish, M. Trainer, J. S. Holloway, T. B. Ryerson, G. Hubler, F. C. Fehsenfeld, and M. J. Evans (2001), Trace gas signatures of the airstreams within North Atlantic cyclones: Case studies from the NARE' 97 aircraft intensive, J. Geophys. Res., 106, 5437-5456.

Donnell, E. A., D. J. Fish, E. M. Dicks, and A. J. Thorpe (2001), Mechanisms for pollutant transport between the boundary layer and the free troposphere, J. Geophys. Res., 106, 7847-7856.

Duce, R. A., C. K. Unni, B. J. Ray, J. M. Prospero, and J. T. Merill (1980), Long-range atmospheric transport of soil dust from Asia to the tropical North Pacific: Temporal variability, Science, 209, 1522-1524.

Esler, J. G., P. H. Haynes, K. S. Law, H. Barjat, K. Dewey, J. Kent, S. Schmitgen, and N. Brough (2003), Transport and mixing between air masses in cold frontal regions during Dynamics and Chemistry of Frontal Zones (DCFZ), J. Geophys. Res., 108(D4), 4142, doi:10.1029/ 2001JD001494.

Folkins, I., R. Chatfield, D. Baumgardner, and M. Profitt (1997), Biomass burning and deep convection in southeastern Asia: Results from ASHOE/ MAESA, J. Geophys. Res., 102, 13,291-13,299.

Fuelberg, H. E., C. M. Kiley, J. R. Hannan, D. J. Westberg, M. A. Avery, and R. E. Newell (2003), Meteorological conditions and transport pathways during the Transport and Chemical Evolution Over the Pacific (TRACE-P) experiment, J. Geophys. Res., 108(D20), 8782, doi:10.1029/2002JD003092. 
Gettelman, A., M. L. Salby, W. J. Randel, and F. Sassi (2001), Convection in the tropical region and stratosphere-troposphere exchange, SPARC Newsl., 17 .

Gheusi, F., and J. Stein (2002), Lagrangian description of airflows using Eulerian passive tracers, Q. J. R. Meteorol. Soc., 128(579), 337-360.

Grant, W. B., et al. (2000), A case study of transport of tropical marine boundary layer and lower tropospheric air masses to the northern midlatitude upper troposphere, J. Geophys. Res., 105, 3757-3769.

Gregory, G. L., J. T. Merrill, M. C. Shipmam, D. R. Blake, G. W. Sachse, and H. B. Singh (1997), Chemical characteristics of tropospheric air over the Pacific Ocean as measured during PEM-West B: Relationship to Asian outflow and trajectory history, J. Geophys. Res., 102, 28,27528,285

Hannan, J. R., H. E. Fuelberg, J. Crawford, G. W. Sachse, and D. R. Blake (2003), Role of wave cyclones in transporting boundary layer air to the free troposphere during the spring 2001 NASA/TRACE-P experiment, J. Geophys. Res., 108(D20), 8785, doi:10.1029/2002JD003105.

Harrold, T. W. (1973), Mechanisms influencing the distribution of precipitation within baroclinic disturbances, Q. J. R. Meteorol. Soc., 99, $232-$ 251

Hess, P. G., and T. Vukicevic (2003), Intercontinental transport, chemical transformations, and baroclinic systems, J. Geophys. Res., 108(D12), 4354, doi:10.1029/2002JD002798.

Hoskins, B. J., and K. I. Hodges (2002), New perspectives on the Northern Hemisphere winter storm tracks, J. Atmos. Sci., 59, 1041-1061.

Husar, R. B., et al. (2001), Asian dust events of April 1998, J. Geophys Res., 106, 18,317-18,330.

Jacob, D. J., J. H. Crawford, M. M. Kleb, V. S. Connors, R. J. Bendura, J. L. Raper, G. W. Sachse, J. C. Gille, L. Emmons, and C. L. Heald (2003) Transport and Chemical Evolution Over the Pacific (TRACE-P) aircraft mission: Design, execution, and first results, J. Geophys. Res., 108(D20), 9000, doi:10.1029/2002JD003276.

Jaffe, D. (2001), Observations of ozone and related species in the northeast Pacific during PHOBEA campaigns: 1 . Ground-based observations at Cheeka Peak, J. Geophys. Res., 106, 7449-7461.

Jaffe, D., et al. (1999), Transport of Asian air pollution to North America Geophys. Res. Lett., 26, 711-714.

Jaffe, D., I. McKendry, T. Anderson, and H. Price (2003), Six 'new' episodes of transpacific transport of air pollutants, Atmos. Environ., 37, $391-404$

Kaneyasu, N., K. Takeuchi, M. Hayashi, S.-I. Fujita, I. Uno, and H. Sasaki (2000), Outflow patterns of pollutants from East Asia to the North Pacific in the winter monsoon, J. Geophys. Res., 105, 17,361-17,377.

Kritz, M. A., J. C. Le Roulley, and E. F. Danielsen (1990), The China Clipper-fast advective transport of radon-rich air from the Asian boundary layer to the upper troposphere near California, Tellus, Ser. B, 42, 4661.

Lafore, J. P., et al. (1994), The Meso-NH atmospheric simulation system, I. Adiabatic formulation and control simulations, Ann. Geophys., 16, $90-$ 109

Liu, H., D. J. Jacob, I. Bey, R. M. Yantosca, B. N. Duncan, and G. W. Sachse (2003), Transport pathways for Asian pollution outflow over the Pacific: Interannual and seasonal variations, J. Geophys. Res., 108(D20), 8786 doi: $10.1029 / 2002$ JD003102.

Mari, C., K. Suhre, R. Rosset, T. S. Bates, B. J. Huebert, A. R. Bandy, D. C. Thornton, and S. Businger (1999), One-dimensional modeling of sulfur species during the First Aerosol Characterization Experiment (ACE-1) Lagrangian B, J. Geophys. Res., 104, 21,733-21,749.

Miyazaki, Y., et al. (2003), Synoptic-scale transport of reactive nitrogen over the western Pacific spring, J. Geophys. Res., 108(D20), 8788 doi:10.1029/2002JD003248.

Newell, R. E., and M. J. Evans (2000), Seasonal changes in pollutant transport to the North Pacific: The relative importance of Asian and European sources, Geophys. Res. Lett., 27, 2509-2512.

Palmer, P. I., D. J. Jacob, D. B. A. Jones, C. L. Heald, R. M. Yantosca, J. A. Logan, G. W. Sachse, and D. G. Streets (2003), Inverting for emissions of carbon monoxide from Asia using aircraft observations over the western Pacific, J. Geophys. Res., 108(D21), 8828, doi:10.1029/2003JD003397.
Pickering, K. E., et al. (2001), Trace gas transport and scavenging in PEMTropics B SPCZ convection, J. Geophys. Res., 106, 32,591-32,602.

Prather, M. J., and D. J. Jacob (1997), A persistent imbalance in $\mathrm{HO}_{\mathrm{x}}$ and $\mathrm{NO}_{\mathrm{x}}$ photochemistry of the upper troposphere driven by deep tropical convection, Geophys. Res. Lett., 24, 3189-3192.

Prospero, J. M., and D. L. Savoie (1989), Effect of continental sources on nitrate concentrations over the Pacific Ocean, Nature, 339, 687-689.

Sachse, G. W., G. F. Hill, L. O. Wade, and M. G. Perry (1987), Fastresponse, high-precision carbon monoxide sensor using a tunable diode laser sensor technique, J. Geophys. Res., 92, 2071-2081.

Schultz, D. M. (2001), Reexamining the cold conveyor belt, Mon. Weather Rev., 129, 2205-2225.

Simpson, I. J., N. J. Blake, D. R. Blake, E. Atlas, F. Flocke, J. H. Crawford, H. E. Fuelberg, C. M. Kiley, S. Meinardi, and F. S. Rowland (2003), Photochemical production and evolution of selected $\mathrm{C}_{2}-\mathrm{C}_{5}$ alkyl nitrates in tropospheric air influenced by Asian outflow, J. Geophys. Res., 108(D20), 8808, doi:10.1029/2002JD002830.

Stohl, A. (2001), A 1-year Lagrangian "climatology" of airstreams in the Northern Hemisphere troposphere and lowermost stratosphere, J. Geophys. Res., 106, 7263-7279.

Stohl, A., and T. Trickl (1999), A textbook example of long-range transport: Simultaneous observation of ozone maxima of stratospheric and North American origin in the free troposphere over Europe, J. Geophys. Res., $104,30,445-30,462$.

Stohl, A., S. Eckhardt, C. Forster, P. James, and N. Spichtinger (2002), On the pathways and timescales of intercontinental air pollution transport, J. Geophys. Res., 107(D23), 4684, doi:10.1029/2001JD001396.

Streets, D. G., and S. T. Waldhoff (2000), Present and future emissions of air pollutants in China: $\mathrm{SO}_{4}, \mathrm{NO}_{\mathrm{x}}$ and $\mathrm{CO}$, Atmos. Environ., 34, $363-$ 374.

Sturman, A. P., and H. A. McGowan (1995), An assessment of boundary layer air mass characteristics associated with topographically induced local wind systems, Boundary Layer Meteorol., 74, 181-193.

Suhre, K., et al. (2000), Chemistry and aerosols in the marine boundary layer: 1-D modeling of the three ACE-2 Lagrangian experiments, Atmos. Environ., 34, 5079-5094.

Talbot, R. W., et al. (2003), Reactive nitrogen in Asian continental outflow over the western Pacific: Results from the NASA Transport and Chemical Evolution Over the Pacific (TRACE-P) airborne mission, J. Geophys. Res., 108(D20), 8803, doi:10.1029/2002JD003129.

Tulet, P., V. Crassier, F. Solmon, D. Guedalia, and R. Rosset (2003), Regional pollution modeling: Description of the Meso-NH-C model and application to a transboundary pollution episode between northern France and southern England, J. Geophys. Res., 108(D1), 4021, doi:10.1029/2000JD000301.

Vay, S., et al. (2003), Influence of regional-scale anthropogenic emissions on $\mathrm{CO}_{2}$ distributions over the western North Pacific, J. Geophys. Res., 108(D20), 8801, doi:10.1029/2002JD003094.

Wild, O., and H. Akimoto (2001), Intercontinental transport of ozone and its precursors in a three-dimensional global CTM, J. Geophys. Res., 106, $27,729-27,744$

Wilkening, K. E., L. A. Barrie, and M. Engle (2000), Transpacific air pollution, Science, 290, 65-67.

Xiao, H., G. R. Carmichael, J. Durchenwald, D. Thornton, and A. Bandy (1997), Long-range transport of $\mathrm{SO}_{x}$ and dust in East Asia during the PEM B experiment, J. Geophys. Res., 102, 28,589-28,612.

Yienger, J. J., M. Galanter, T. A. Holloway, M. J. Phadnis, S. K. Guttikunda, G. R. Carmichael, W. J. Moxim, and H. Levy II (2000), The episodic nature of air pollution transport from Asia to North America, J. Geophys. Res., 105, 26,931-26,945.

M. J. Evans, D. J. Jacob, and P. I. Palmer, Division of Engineering and Applied Science, Harvard University, Cambridge, MA 02138, USA.

C. Mari, Laboratoire d'Aérologie, UMR 5560 CNRS/Université Paul Sabatier, F-31400 Toulouse, France. (marc@aero.obs-mip.fr)

G. W. Sachse, NASA Langley Research Center, Hampton, VA 23681, 